kandidátské práce byla původně i př́loha, obsahující nejméně deset jazykových map, ta se však pravděpodobně do současnosti nezachovala, $\mathrm{z}$ tohoto důvodu byly všechny autorovy odkazy na přiložené mapy z textu vymazány. Práce kromě závěru neobsahovala ani cizojazyčné resumé, proto tvůrci knihy připojili k textu krátký souhrn v angličtině (s. 263-265), v němž uvádějí základní body Kotuličovy koncepce vývoje východoslovenských nářečí a podávají stručné celkové hodnocení díla. Představovanou publikaci uzavírá Obsah (s. 267-269).

Knižním vydáním kandidátské práce se zaplnila velká mezera v slovenské historické jazykovědě a v slovenské dialektologii. Velkou část disertace tvoří četné nářeční a historické jazykové záznamy, které Kotulič bud’ excerpoval z publikovaných pramenů, nebo získal vlastními terénními sběry či bádáním v archivech. Excerpoval historické dokumenty $\mathrm{v}$ téměř všech východoslovenských a relevantních budapeštských archivech. Takto získané údaje představují velmi cenný př́nos disertace a zcela jistě budou užitečné i pro další badatele.

Dobrou zprávou pro všechny zájemce o kandidátskou práci Izidora Kotuliče je její dostupnost též v elektronické podobě na adrese <http://www.academia.edu/34892007/ Historické_hláskoslovie_a_tvaroslovie_východoslovenských_nárečí_1957_>.

Petra Přadková

https://doi.org/10.5817/OS2018-4-10

\title{
Znovu o kouzlu překladu
}

KREJČOVÁ, E., STALYANOVA, N.: Kouzlo a umění překladu. Brno: Masarykova univerzita, 2018, 80 s., ISBN 978-80-210-9017-0.

Profese prrekladatele a tlumočníka je výzvou pro každého, kdo se rozhodl se jí věnovat. Vyžaduje totiž jak talent, tak i velmi dobré ovládání nejen jazyka, z/do kterého se překládá, ale i vlastní mateřštiny. Překladatel musí mít široký rozhled, specifické znalosti a ovládat alespoň do určitého stupně terminologie nejrůznějších oblastí života. Každý filolog se dříve či později „osobně setká“ s překladem a toto setkání někdy přeroste v jeho profesní životní lásku. Právě pro filology - studenty bulharštiny na zahraničních univerzitách, kteří se seznamují s tajemstvími překládání a to jak specializovaných textů, tak i odborné literatury - je určena príručka Kouzlo a umění prekladu, která vyšla v předvečer Mezinárodního dne překladatelů (3o. záŕí svátek sv. Jeronýma, patrona překladatelů). Díky jejímu zpř́stupnění online v digitální číárně Masarykovy univerzity je knížka př́stupná nejen kmenovým studentům MU, ale každému, kdo o ni ve virtuálním světě projeví zájem. 
Příručka přináší cenné praktické i teoretické informace. Texty obsažené v př́ručce mají na konci vždy uveden př́slušný zdroj a jsou rozděleny do dvou částí - první je spojená s překladatelskou profesí, se společenskými oblastmi, kde se tlumočník může profesně realizovat, se zvláštnostmi jednotlivých druhů specializovaných překladů apod. Druhou část tvoří rozhovory s významnými bulharskými překladateli umělecké literatury, v nichž tyto osobnosti sdílejí své zkušenosti a přinášejí své pohledy na aktuální otázky důležité pro každého překladatele i pro překládání jako umění a lidskou a profesní zkušenost. Každý z překladatelů se dělí o své zkušenosti a názory na to, jaká je úloha překladatele při převádění určitého literárního díla do jiného jazykového kódu: co je to, co dělá určitý umělecký překlad kvalitním? Jaké jsou nejčastější obtí̌̌e při překládání? Jaké jsou největší výzvy při práci s originálním textem? Jakou fázi překladatelské činnosti můžeme označit za tvưrčí? Je překladatel spoluautor? Jaká je role překladatele uměleckého textu? Je důležité, do jaké míry př̌kladatel ovládá svůj mateřský jazyk? Prostřednictvím názorů zkušených překladatelů budou mít studenti možnost seznámit se s tím, jakým způsobem se text př̌evádí tak, aby byl dostatečně srozumitelný a př́stupný čtenáři z jiného jazykového a kulturního okruhu a současně aby bylo zachováno co nejvíce prvků specifické kulturní sémantiky originálu, a dále do jaké hloubky by měl překladatel ovládat nejjemnější detaily z kultury a dějin země, z níž vzešel originální text, ale to samé i ohledně vlastní kultury, historie a jazyka, což předpokládá vysokou úroveň vládnutí oběma jazyky - cizím i mateřským.

V textech př́ručky je překlad naprosto korektně prezentován ne jako pouhá záměna jednotek jednoho jazyka za jednotky jazyka druhého, ale jako komplexní činnost, při které musí překladatel čelit různým výzvám a obtížím. Překladatelé budoucí i stávající, pro něž sebevzdělávání představuje nikdy nekončící proces, jsou si vědomi složitosti problematiky velkého množství přístupů a metod používaných při překladu.

Publikace, která je zaměřena didakticko-pragmaticky, může podnítit i akademické diskuse o translatologii - o slovech, o vzájemných kontaktech mezi jazyky a společnostmi, o překladech jako bohatství a kapitálu v kultuře každého národa. Studentskému obecenstvu jsou $\mathrm{v}$ této publikaci př̀edstaveni zkušení bulharští překladatelé, kteří sdílejí svou osobní zkušenost s rolí tzv. mediátora mezi jazyky a kulturami a pokládají otázky, na které narazí každý absolvent filologického studia na prahu své profesionální realizace. Tato příručka připomíná (nejen) humanitně vzdělaným lidem, že překlad znamená obrovskou zodpovědnost, jasné povědomí o tom, že překladatel a překlad jsou pouhým mostem mezi dvěma jazyky, dvěma kulturami. A nutí nás položit si rétorickou otázku: jak by vypadaly naše kultura a civilizace bez přkladu? 